\title{
Manipulating bovine granulosa cell energy metabolism limits inflammation
}

\author{
Anthony D. Horlock ${ }^{1}$, Thomas J. R. Ormsby ${ }^{1}$, Martin J. D. Clift ${ }^{1}$, José E. P. Santos ${ }^{2}$, John J. Bromfield ${ }^{2}$ and I. \\ Martin Sheldon ${ }^{1}$ \\ ${ }^{1}$ Swansea University Medical School, Swansea University, Swansea SA2 8PP, UK. \\ ${ }^{2}$ Department of Animal Sciences, University of Florida, Gainesville 32611, USA.
}

Correspondence should be addressed to I M Sheldon, Institute of Life Science, Swansea University Medical School, Swansea University, Swansea SA2 8PP, UK.

E-mail: i.m.sheldon@swansea.ac.uk

Short title: Granulosa cell immunometabolism

Keywords: Ovary, Innate immunity, Lipopolysaccharide, AMPK, mTOR, Cattle

\begin{abstract}
Bovine granulosa cells are often exposed to energy stress, due to the energy demands of lactation, and exposed to lipopolysaccharide from postpartum bacterial infections. Granulosa cells mount innate immune responses to lipopolysaccharide, including the phosphorylation of mitogen-activated protein kinases and production of proinflammatory interleukins. Cellular energy depends on glycolysis, and energy stress activates intracellular AMPK (AMP-activated protein kinase), which in turn inhibits mTOR (mechanistic target of rapamycin). Here, we tested the hypothesis that manipulating glycolysis, AMPK or mTOR to mimic energy stress in bovine granulosa cells limits the inflammatory responses to lipopolysaccharide. We inhibited glycolysis, activated AMPK or inhibited mTOR in granulosa cells isolated from $4-8 \mathrm{~mm}$ and $>8.5 \mathrm{~mm}$ diameter ovarian follicles, and then challenged the cells with lipopolysaccharide and measured the production of interleukins IL- $1 \alpha$, IL-1 $\beta$, and IL-8. We found that inhibiting glycolysis with 2-deoxy-D-glucose reduced lipopolysaccharide-stimulated IL-1 $\alpha>80 \%$, IL-1 $\beta>90 \%$, and IL-8 $>65 \%$ in granulosa cells from $4-8 \mathrm{~mm}$ and $>8.5 \mathrm{~mm}$ diameter ovarian follicles. Activating AMPK with AICAR also reduced lipopolysaccharide-stimulated IL- $1 \alpha>60 \%$, IL- $1 \beta>75 \%$, and IL-8 $>20 \%$, and shortened the duration of lipopolysaccharide-stimulated phosphorylation of the mitogen-activated protein kinase ERK1/2 and JNK. However, only the mTOR inhibitor Torin 1, and not rapamycin, reduced lipopolysaccharide-stimulated IL- $1 \alpha$ and IL-1 $\beta$. In conclusion, manipulating granulosa cell energy metabolism with a glycolysis inhibitor, an AMPK activator, or an mTOR inhibitor, limited inflammatory responses to lipopolysaccharide. Our findings imply that energy stress compromises ovarian follicle immune defences.
\end{abstract}

\section{Introduction}

Ovarian follicle function is often perturbed by energy stress and bacterial infections in postpartum dairy cows (Leroy, et al. 2008, Sheldon, et al. 2019, Sheldon, et al. 2002). Granulosa cells in ovarian follicles are exposed to energy stress when cows are unable to consume enough food to meet their energy demands, around the time of parturition and during lactation. These granulosa cells are then also exposed to lipopolysaccharide (LPS) if Gramnegative bacteria proliferate in the uterus, mammary gland, or rumen during the postpartum period (Bromfield, et al. 2015, Piersanti, et al. 2019). In the absence of immune cells within ovarian follicles, the granulosa cells are responsible for innate immunity and mounting inflammatory responses to LPS (Bromfield and Sheldon 2011, Herath, et al. 2007). However, whether energy stress alters granulosa cell inflammatory responses to LPS is unclear.

Granulosa cells are central to the emergence and development of 4-8 $\mathrm{mm}$ diameter ovarian follicles, selection and growth of dominant follicles $>8.5 \mathrm{~mm}$ diameter, and ovulation of competent oocytes (Fortune 1994, Ginther, et al. 1996). However, postpartum uterine disease reduces follicle growth rate and oestradiol secretion, inhibits ovulation, and reduces conception rates (LeBlanc, et al. 2002, Sheldon, et al. 2019, Sheldon, et al. 2002). Animals with uterine disease have LPS in their follicular fluid, and intrafollicular injection of LPS reduces follicle growth 
rate and delays ovulation (Cheong, et al. 2017, Gindri, et al. 2019, Herath, et al. 2007, Piersanti, et al. 2019). Other sources of LPS include mastitis, ruminal acidosis, and intestinal barrier dysfunction (Bidne, et al. 2018, Dosogne, et al. 2002, Khafipour, et al. 2009). When LPS binds to Toll-like receptor 4 (TLR4), immune cells release inflammatory cytokines, such as interleukins IL-1 and IL-6, and the chemokine IL-8 (Moresco, et al. 2011). However, healthy ovarian follicles lack immune cells within the membrana granulosa (Bromfield and Sheldon 2011, Irving-Rodgers, et al. 2001, Spanel-Borowski, et al. 1997). Instead, granulosa cells express TLR4, and LPS activates mitogen-activated protein kinase (MAPK) signalling and stimulates the production of IL-1 $\beta$, IL-6 and IL-8 (Bromfield and Sheldon 2011, Herath, et al. 2007, Price, et al. 2013, Price and Sheldon 2013). As well as being pro-inflammatory mediators IL-1 $\alpha$, IL-1 $\beta$, IL- 6 and IL-8 affect ovarian follicle growth and function (Gérard, et al. 2004, Spicer and Alpizar 1994, Uri-Belapolsky, et al. 2014).

Energy stress is caused by energy demand exceeding supply around the time of parturition and during lactation. This energy stress impairs immune cell function, perturbs ovarian follicle growth and function, and increases the risk of uterine disease (Beam and Butler 1997, Hammon, et al. 2006, LeBlanc 2012, Leroy, et al. 2008, Leroy, et al. 2004). Inflammatory responses to LPS are also energetically demanding. An extra $2.1 \mathrm{Kg} / \mathrm{d}$ glucose is required to respond to LPS infusion, which is comparable with $2.7 \mathrm{Kg} / \mathrm{d}$ glucose needed to produce 40 litres milk (Habel and Sundrum 2020, Kvidera, et al. 2017). Cellular energy metabolism is regulated by glycolysis, AMPK (AMPactivated protein kinase), and mTOR (mechanistic target of rapamycin) (Hardie, et al. 2012, Murray, et al. 2015, O'Neill, et al. 2016, Zoncu, et al. 2011). The first enzyme in glycolysis, hexokinase, controls the rate of conversion of glucose to pyruvate, to supply the Krebs cycle and generate ATP. During energy stress, increased ratios of AMP:ATP results in phosphorylation of AMPK, which stimulates catabolic pathways such as glycolysis, and inhibits anabolic pathways that consume ATP such as protein synthesis (Hardie, et al. 2012). Phosphorylated AMPK also inhibits mTOR, which further limits anabolic pathways (Hardie, et al. 2012, Zoncu, et al. 2011).

Metabolism and immunity are highly integrated, with energy stress altering immune cell responses to LPS (Dror, et al. 2017, Lachmandas, et al. 2016, Murray, et al. 2015, O'Neill, et al. 2016). An example of immunometabolism is that inhibiting glycolysis with 2-deoxy-D-glucose suppresses LPS-stimulated IL-1 $\beta$ in murine macrophages (Tannahill, et al. 2013). However, the role of immunometabolism in the ovary is unclear. The present study aimed to explore whether energy stress alters inflammatory responses to LPS in granulosa cells. We hypothesized that manipulating glycolysis, AMPK or mTOR to mimic energy stress in granulosa cells would limit the inflammatory responses to lipopolysaccharide. To test this hypothesis, we used bovine granulosa cells isolated from 4-8 mm and $>8.5 \mathrm{~mm}$ diameter ovarian follicles. We treated cells with small molecules to inhibit glycolysis, activate AMPK or inhibit mTOR, and then challenged the cells with LPS to measure their IL-1 $\alpha$, IL-1 $\beta$ and IL-8 inflammatory responses.

\section{Materials and Methods}

\section{Ethical statement}

Ovaries were collected from cattle after slaughter and processing, during the normal work of a commercial slaughterhouse, with approval from the United Kingdom Department for Environment, Food and Rural Affairs under the Animal By-products Registration (EC) No. 1069/2009 (registration number U1268379/ABP/OTHER).

\section{Granulosa cell culture}

Ovaries were collected within 15 min of slaughter from post pubertal, non-pregnant, healthy mixed-breed beef heifers. Ovaries were transported to the laboratory in Medium 199 (Thermo Fisher Scientific, Loughborough, UK) supplemented with $1 \%$ Antibiotic Antimycotic Solution (Merck, Gillingham, UK) and $0.1 \%$ bovine serum albumin (BSA; Merck).

Granulosa cells were isolated and cultured as described previously (Price, et al. 2013). Briefly, ovaries were first rinsed in 70\% ethanol and then sterile phosphate buffered saline (PBS; Thermo Fisher Scientific). Mural granulosa cells were then aspirated from follicles using a sterile 20-gauge needle and $5 \mathrm{ml}$ LPS-free syringe (BD Medical, Oxford, UK) into collection medium, comprising Medium 199 supplemented with 0.5\% w/v BSA, $25 \mathrm{mM} \mathrm{HEPES}$ (4-[2-hydroxyethyl] piperazine-1-ethanesulfonic acid), 1\% Antibiotic Antimycotic Solution, and $0.005 \% \mathrm{w} / \mathrm{v}$ heparin (all Merck). Granulosa cells were aspirated from 4-8 mm diameter follicles to represent cells from emerged follicles, and $>8.5 \mathrm{~mm}$ diameter follicles to represent cells from dominant follicles (Fortune 1994). Granulosa cells were pooled from the ovaries of 10-20 animals, and washed twice in granulosa cell culture 
medium, comprising Medium 199 (Thermo Fisher Scientific; $5.55 \mathrm{mM}$ glucose) supplemented with 10\% heatinactivated fetal bovine serum (Biosera, Ringmer, UK), 1\% Antibiotic Antimycotic Solution, 1\% InsulinTransferrin-Selenium (Corning, Palo Alto, USA) and, 2 mM glutamine (GlutaMAX, Thermo Fisher Scientific). The cells were counted and seeded into 24-well plates (TPP, Trasadingen, Switzerland) at a density of 750,000 cells in $0.5 \mathrm{ml}$ of granulosa cell culture medium. The cells were incubated at $38.5^{\circ} \mathrm{C}$, in a humidified atmosphere of air containing $5 \% \mathrm{CO}_{2}$.

\section{Granulosa cell treatment and challenge}

After an initial $18 \mathrm{~h}$ culture period, the medium was aspirated, and the cells were cultured with vehicle or treatments in $0.5 \mathrm{ml}$ of granulosa cell culture medium. The experimental rationale was to use small molecules to manipulate glycolysis, AMPK or mTOR, or to alter the glucose supply, and then challenge the cells with LPS to evaluate inflammation. The first enzyme in the glycolysis pathway, hexokinase, was inhibited by treating cells for $2 \mathrm{~h}$ with 50-1000 $\mu \mathrm{M}$ 2-deoxy-D-glucose (Merck) to model energy stress, as described previously (Lee, et al. 2020, Tannahill, et al. 2013, Zhao, et al. 2017). Subsequent experiments used $1 \mathrm{mM}$ 2-deoxy-D-glucose, based on the preceding experiment, and the use of $1 \mathrm{mM}$ 2-deoxy-D-glucose to explore how glycolysis affects innate immunity (Tannahill, et al. 2013, Zhao, et al. 2017).

Energy stress activates AMPK, and so we treated cells for $2 \mathrm{~h}$ with 0.01-1 mM AICAR (5-aminoimidazole-4carboxamide1-beta-D-ribofuranoside; Merck) to activate AMPK (Corton, et al. 1995), as validated previously by showing that AICAR-stimulated phosphorylation of AMPK in bovine granulosa cells (Tosca, et al. 2007). Subsequent experiments used $1 \mathrm{mM}$ AICAR, based on the preceding experiment, and the use of $1 \mathrm{mM}$ AICAR to activate AMPK in granulosa cells from rats, chickens and cattle (Tosca, et al. 2007, Tosca, et al. 2006, Tosca, et al. 2005), and bovine endometrial cells (Turner, et al. 2016).

As AMPK inhibits mTOR, we also treated cells for $2 \mathrm{~h}$ with the mTOR complex 1 (mTORC1) inhibitor (5-500 $\mathrm{nM}$ rapamycin; Merck) or the mTORC1/2 inhibitor (10-150 nM Torin 1, 1-[4-[4-(1-Oxopropyl)-1-piperazinyl]3-(trifluoromethyl) phenyl]-9 (3-quinolinyl)-benzo[h]-1,6-naphthyridin-2(1H)-one; Bio-Techne, Abingdon, UK), as described previously (Oshiro, et al. 2004, Thoreen, et al. 2009). Subsequent experiments used $500 \mathrm{nM}$ rapamycin and $50 \mathrm{nM}$ Torin 1 , based on the preceding experiment, and the use of similar concentrations to investigate responses to LPS in human leukocytes (Zhang, et al. 2019), and the use of $100 \mathrm{nM}$ Torin 1 in mouse granulosa cells (Shen, et al. 2017). A glucocorticoid, $1 \mu \mathrm{M}$ dexamethasone (Merck), was used as a reference antiinflammatory agent (Bhattacharyya, et al. 2007).

To explore the requirements for glucose, granulosa cells were treated for $24 \mathrm{~h}$ with a range of concentrations of glucose (0-5 mM) added to glucose-free DMEM (Thermo Fisher Scientific; glucose-free M199 medium was not available), supplemented with $10 \%$ heat-inactivated fetal bovine serum (supplying $0.79 \mathrm{mM}$ glucose at final concentration), 1\% Antibiotic Antimycotic Solution, 1\% Insulin-Transferrin-Selenium, and 2 mM glutamine.

After each treatment period, the cells were challenged for $24 \mathrm{~h}$ by adding $0.5 \mathrm{ml}$ of either granulosa cell culture medium (control) or medium providing a final concentration of $1 \mu \mathrm{g} / \mathrm{ml}$ ultrapure LPS from E. coli serotype 0111:B4 (InvivoGen, Toulouse, France), in the continuing presence of the treatments. The concentration of LPS and duration of challenge was based on previous experiments using a range of concentrations of $1 \mathrm{ng} / \mathrm{ml}$ to 10 $\mu \mathrm{g} / \mathrm{ml}$ LPS, and on IL-1 $\beta$, IL-6 and IL-8 responses to $1 \mu \mathrm{g} / \mathrm{ml}$ LPS in bovine granulosa cells isolated from 4-8 and > $8.5 \mathrm{~mm}$ diameter follicles (Bromfield and Sheldon 2011, Price, et al. 2013, Price and Sheldon 2013). As we hypothesised that treatments might reduce inflammation, as in murine macrophages (Tannahill, et al. 2013), we used a relatively high concentration of $1 \mu \mathrm{g} / \mathrm{ml}$ LPS to stimulate robust inflammatory responses.

At the end of each experiment, granulosa cell supernatants were collected for the measurement of the representative inflammatory mediators IL- $1 \alpha$, IL- $1 \beta$ and IL- 8 by enzyme-linked immunosorbent assay (ELISA), and cell viability and proliferation was estimated using the MTT assay or cell lysates were collected for Western blotting. Each experiment was repeated on at least three independent occasions, with each replicate using granulosa cells pooled from the ovaries of 10-20 animals.

\section{ELISA}

Bovine IL-1 $\alpha$ ELISA was performed as described and validated previously (Healy, et al. 2014); using polyclonal rabbit anti-bovine IL-1 $\alpha$ capture antibody (Kingfisher Biotech, Saint Paul, USA; RRID: AB_2833237), 
recombinant IL-1 $\alpha$ protein (Kingfisher Biotech, \#RP0097B), biotinylated polyclonal anti-bovine IL-1 $\alpha$ (Kingfisher Biotech; RRID: AB_2833238) and avidin HRP (Fisher Scientific; \#18410051). Bovine IL-1 $\beta$ ELISA was performed using a kit according to the manufacturer's instructions (Thermo Fisher Scientific; RRID: AB_2833244). Bovine IL-8 ELISA was performed as described and validated previously (Cronin, et al. 2015); using monoclonal anti-ovine IL-8 capture antibody (Bio-Rad, Hercules, CA, USA; RRID: AB_322152), recombinant IL-8 protein (Kingfisher Biotech; \#RP0023B), polyclonal rabbit anti-sheep IL-8 detection antibody (Bio-Rad; RRID: AB_322153) and HRP-conjugated goat anti-rabbit antibody (Dako, Glostrup, Denmark; RRID: AB_2617138). The limits of detection were $12.5 \mathrm{pg} / \mathrm{ml}$ for IL- $1 \alpha, 31.3 \mathrm{pg} / \mathrm{ml}$ for IL-1 $\beta$, and $62.5 \mathrm{pg} / \mathrm{ml}$ for IL-8; the inter-assay and intra-assay coefficients of variation were all $<7 \%$ and $<9 \%$, respectively.

\section{MTT assay}

The MTT assay has been used previously as an indicator of cell viability, proliferation and cytotoxicity following treatment with 2-deoxy-D-glucose, AICAR, rapamycin and Torin 1 (Aft, et al. 2002, Giubellino, et al. 2013, Kim, et al. 2008). Granulosa cell MTT assays were performed as described previously (Price, et al. 2013). Briefly, after supernatants were collected, cells were incubated for $1 \mathrm{~h}$ in granulosa cell culture medium containing $0.5 \mathrm{mg} / \mathrm{ml}$ MTT (3-(4,5-dimethylthiazol-2-yl)-2,5-diphenyltetrazolium; Merck). The supernatants were discarded, the cells lysed using dimethyl sulfoxide (Merck), and optical density measured at $570 \mathrm{~nm}\left(\mathrm{OD}_{570}\right)$ using a POLARstar Omega plate reader (BMG Labtech, Ortenberg, Germany).

\section{Western blotting}

First, we explored the effects of the treatments alone on p70 S6 kinase (p70S6K also known as ribosomal protein S6 kinase beta-1), which induces proteins synthesis at ribosomes (Kimura, et al. 2003), and acetyl-CoA carboxylase, which is a downstream target of AMPK and the biomarker for AMPK activation (González, et al. 2020, Hardie, et al. 2012). Granulosa cells from 4-8 mm or $>8.5 \mathrm{~mm}$ diameter ovarian follicles were treated for $0,10,20,30,60$ or $120 \mathrm{~min}$ with $1 \mathrm{mM}$ AICAR to examine activation of acetyl-CoA carboxylase, or for $24 \mathrm{~h}$ with vehicle, $1 \mathrm{mM}$ 2-deoxy-D-glucose, $1 \mathrm{mM}$ AICAR, $500 \mathrm{nM}$ rapamycin or $50 \mathrm{nM}$ Torin 1; the effect of 1 $\mu \mathrm{g} / \mathrm{ml}$ LPS was also examined.

Secondly, we explored the effects of AICAR or Torin 1 treatment followed by LPS challenge on MAPK signalling, because LPS induces MAPK signalling in granulosa cells (Bromfield and Sheldon 2011, Price, et al. 2013). Granulosa cells from 4-8 $\mathrm{mm}$ or $>8.5 \mathrm{~mm}$ diameter ovarian follicles were treated for $2 \mathrm{~h}$ with granulosa cell culture medium containing vehicle, or $1 \mathrm{mM}$ AICAR or $50 \mathrm{nM}$ Torin 1 , and then challenged for $0,10,20,30$, 60 or 120 min with medium containing a final concentration of $1 \mu \mathrm{g} / \mathrm{ml}$ LPS.

At the end of these experiments, the cells were washed with $300 \mu \mathrm{l} /$ well of ice-cold phosphate buffered saline (PBS; Gibco) and lysed with $100 \mu \mathrm{l} /$ well PhosphoSafe Extraction Reagent (Novagen, Darmstadt, Germany), followed by protein extraction and quantification (DC assay; Bio-Rad). Proteins (10 $\mu \mathrm{g}$ ) were electrophoresed on a $10 \%$ or $12 \%$ polyacrylamide gel, transferred onto a polyvinylidene difluoride membrane (GE Healthcare, Chalfont, St Giles, UK), blocked for $1 \mathrm{~h}$ in 5\% BSA in Tris-buffered saline-Tween 20 (TBS-Tween), and probed overnight with primary antibodies diluted 1:1000 in 5\% BSA TBS-Tween. The primary antibodies were phosphop70 S6 kinase (Cell Signaling, Danvers, MA, USA; RRID: AB_2269803), p70 S6 kinase (Cell Signaling; RRID: AB_331676), phospho-ACC (Cell Signaling; RRID: AB_330337), ACC (Cell Signaling; RRID: AB_2219400), phospho-AMPK Thr172 (Cell Signaling; RRID: AB_331250), AMPK (Cell Signaling; RRID: AB_10622186), diphosphorylated ERK1/2 (Merck; RRID: AB_477245), ERK1/2 (Abcam, Cambridge, UK; RRID: AB_2297336), phospho-JNK (Cell Signaling; RRID: AB_331659), and JNK (Cell Signaling; RRID: AB_2250373). After three $5 \mathrm{~min}$ washes in TBS-Tween, membranes were incubated for 60 min with 1:2500 dilution HRP-linked anti-mouse IgG (Cell Signaling; RRID: AB_330924) or anti-rabbit IgG (Cell Signaling; RRID: AB_2099233). After a final 3 washes, protein reactivity was assessed by enhanced chemiluminescence (Clarity Western ECL substrate; Bio-Rad). After imaging, membranes were stripped for 7 min with Restore Western Blot Stripping Buffer (Fisher Scientific) and re-probed with another primary antibody, or with 1:1000 dilution $\beta$-actin (Abcam; RRID: AB_306371) or $\alpha$-tubulin (Cell Signalling; RRID:AB_2619646) to normalize protein loading. Images of whole blots were captured using a ChemiDoc XRS System (Bio-Rad; Supplemental Figure 1). The background-normalized peak band density was measured in the images for each protein using Fiji (Schindelin, et al. 2012); target protein bands were normalized to $\beta$-actin or $\alpha$-tubulin, and phosphorylated proteins were normalized to their cognate total protein. 


\section{Statistics}

The statistical unit was each independent culture of granulosa cells. Statistical analysis was performed using GraphPad Prism version 8.4.2 (GraphPad Software, San Diego, California, USA). Data were analysed using oneway or two-way ANOVA, as reported in Results, followed by Dunnett's post hoc tests. Data are presented as dot plots or as arithmetic mean (SEM), and $\mathrm{P}<0.05$ was considered significant.

\section{Results}

\section{Inhibiting glycolysis reduced granulosa cell inflammatory responses to LPS}

Granulosa cell defences are important if ovarian follicles are exposed to LPS during the postpartum period, and yet there is often concurrent energy stress (Beam and Butler 1997, Cheong, et al. 2017, Herath, et al. 2007, Leroy, et al. 2004, Piersanti, et al. 2019). We first used 2-deoxy-D-glucose to inhibit glycolysis and model energy stress, and ultrapure LPS from E. coli to stimulate inflammatory responses in granulosa cells, as described previously (Hirschfeld, et al. 2000, Lee, et al. 2020, Price, et al. 2013, Tannahill, et al. 2013, Zhao, et al. 2017). Granulosa cells, isolated from 4-8 mm or from $>8.5 \mathrm{~mm}$ diameter follicles, were treated with vehicle or 2-deoxy-D-glucose for $2 \mathrm{~h}$ prior to and then during a $24 \mathrm{~h}$ challenge with control medium or medium containing $1 \mu \mathrm{g} / \mathrm{ml}$ LPS. The LPS challenge stimulated inflammatory responses, with higher concentrations of IL- $1 \alpha$, IL- $1 \beta$ and IL- 8 in cell supernatants compared with the control challenge in granulosa cells from $4-8 \mathrm{~mm}(\mathrm{P}<0.001 ;$ Fig. 1$)$ and $>8.5$ $\mathrm{mm}$ diameter follicles ( $\mathrm{P}<0.001$; Fig. 2). However, treating granulosa cells with 2-deoxy-D-glucose reduced LPS-stimulated IL-1 $\alpha$, IL-1 $\beta$, and IL-8, without significantly altering cell viability, in granulosa cells from both 4-8 mm (Fig. 1A-D) and $>8.5 \mathrm{~mm}$ diameter follicles (Fig. 2A-D). Specifically, compared with vehicle, treatment with $500 \mu \mathrm{M}$ 2-deoxy-D-glucose reduced LPS-stimulated IL- $1 \alpha$ by $>80 \%$, IL- $1 \beta$ by $>90 \%$, and IL- 8 by $>65 \%$ for cells from 4-8 $\mathrm{mm}$ and $>8.5 \mathrm{~mm}$ diameter follicles.

A

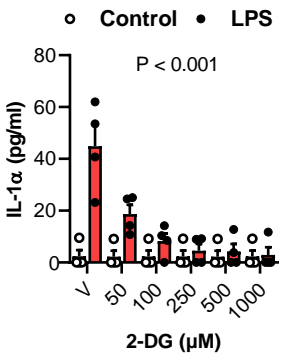

E

- Control - LPS

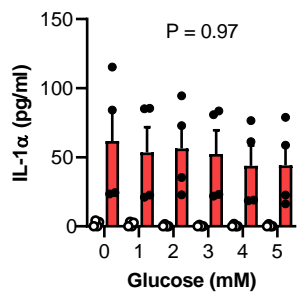

B

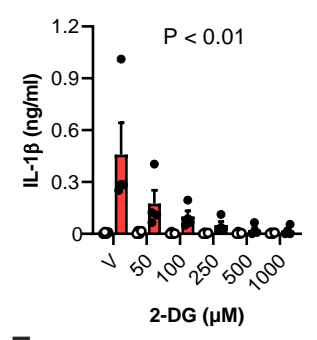

$\mathbf{F}$

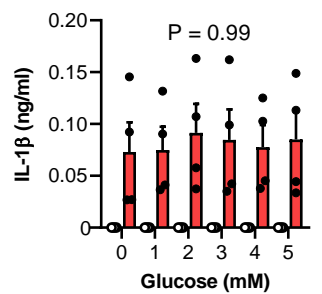

C
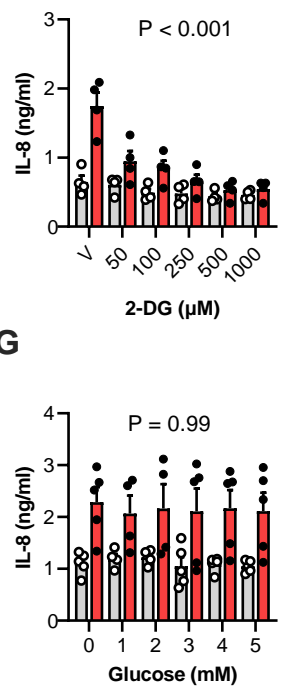

D

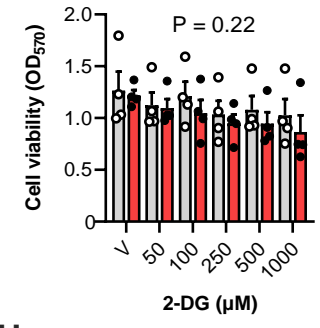

H

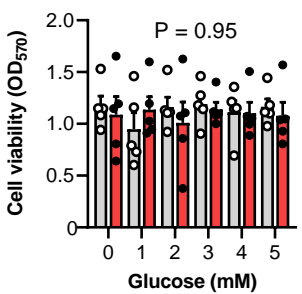

Figure 1. Inhibiting glycolysis limits LPS-stimulated inflammation in granulosa cells.

Granulosa cells isolated from 4-8 mm diameter ovarian follicles were cultured with vehicle (V), or the indicated final concentrations of 2-deoxy-D-glucose for $2 \mathrm{~h}$ (2-DG, A-D), or the indicated concentrations of glucose for 24 $\mathrm{h}(\mathrm{E}-\mathrm{H})$; followed by a $24 \mathrm{~h}$ challenge with control medium (O) or medium containing $1 \mu \mathrm{g} / \mathrm{ml} \mathrm{LPS}(\bullet)$, in the presence of the treatments. Supernatant IL-1 $\alpha$ (A, E), IL-1 $\beta$ (B, F) and IL-8 (C, G) was measured by ELISA, and cell viability assessed by MTT assay (D, H). Data from independent experiments are presented as dot plots, with bars indicating the mean (SEM). Data were analysed by two-way ANOVA, and P-values reported for the effect of treatment on responses to LPS. 
Although inhibiting glycolysis has widespread effects on metabolic pathways and inflammation (Murray, et al. 2015, O'Neill, et al. 2016), one consideration was that limiting glucose may be sufficient to reduce inflammatory response to LPS. Thus, we treated granulosa cells for $24 \mathrm{~h}$ with a range of concentrations of glucose $(0$ to $5 \mathrm{mM})$ added to glucose-free culture medium, in the presence of $2 \mathrm{mM}$ glutamine and $10 \%$ fetal bovine serum (supplying $0.79 \mathrm{mM}$ glucose), followed by a $24 \mathrm{~h}$ challenge with control medium or medium containing $1 \mu \mathrm{g} / \mathrm{ml} \mathrm{LPS}$. However, glucose did not significantly alter LPS-stimulated IL- $1 \alpha$, IL-1 $\beta$ or IL-8, or alter the viability of granulosa cells from either $4-8 \mathrm{~mm}$ (Fig. 1E-H) or > $8.5 \mathrm{~mm}$ diameter follicles (Fig. $2 \mathrm{E}-\mathrm{H})$. These data provide evidence that inhibiting glycolysis to mimic energy stress limited LPS-induced inflammation in granulosa cells from both 4-8 $\mathrm{mm}$ and $>8.5 \mathrm{~mm}$ diameter follicles, but inflammation was not simply dependent on the glucose supply.

A

- Control • LPS

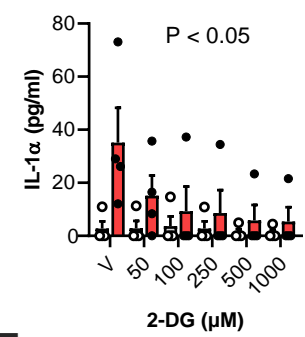

E

- Control • LPS

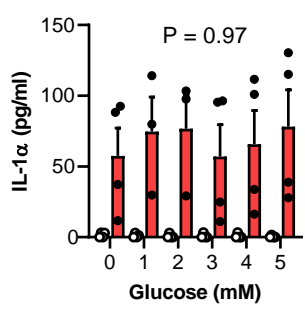

B

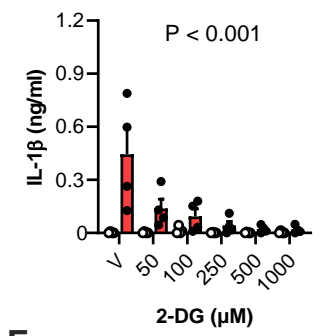

$\mathbf{F}$

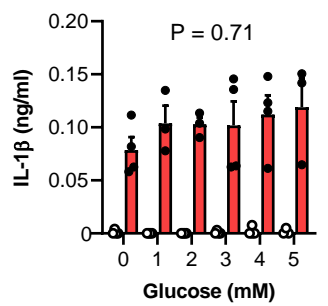

C

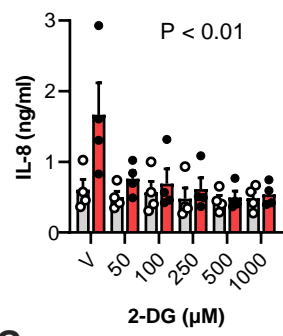

G

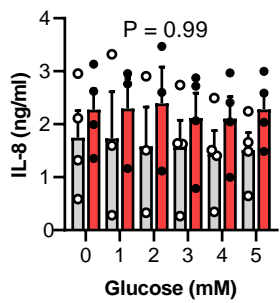

D

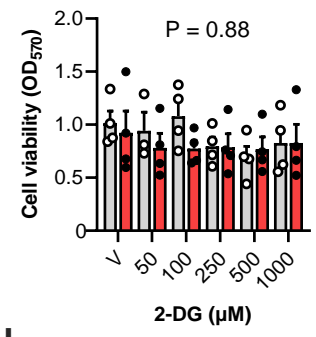

H

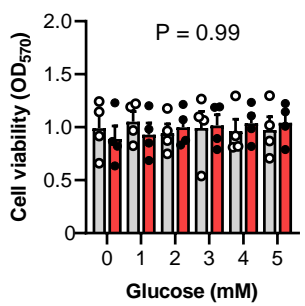

Figure 2. Inhibiting glycolysis limits LPS-stimulated inflammation in granulosa cells.

Granulosa cells isolated from $>8.5 \mathrm{~mm}$ diameter ovarian follicles were cultured with vehicle $(\mathrm{V})$, or the indicated final concentrations of 2-deoxy-D-glucose for $2 \mathrm{~h}$ (2-DG, A-D), or the indicated concentrations of glucose for 24 $\mathrm{h}(\mathrm{E}-\mathrm{H})$; followed by a $24 \mathrm{~h}$ challenge with control medium (O) or medium containing $1 \mu \mathrm{g} / \mathrm{ml} \mathrm{LPS}(\bullet)$, in the presence of the treatments. Supernatant IL-1 $\alpha$ (A, E), IL-1 $\beta$ (B, F) and IL-8 (C, G) was measured by ELISA, and cell viability assessed by MTT assay (D, H). Data from independent experiments are presented as dot plots, with bars indicating the mean (SEM). Data were analysed by two-way ANOVA, and P-values reported for the effect of treatment on responses to LPS.

\section{AMPK and mTOR reduced granulosa cell inflammatory responses to LPS}

Cellular energy metabolism is regulated by AMPK and mTOR, with energy stress activating AMPK and inhibiting mTOR (Hardie, et al. 2012, Zoncu, et al. 2011). To screen for effects of AMPK and mTOR, granulosa cells were treated for $2 \mathrm{~h}$ prior to and during a $24 \mathrm{~h}$ LPS challenge, with $1 \mathrm{mM}$ AICAR to activate AMPK, $500 \mathrm{nM}$ rapamycin to inhibit mTORC1, or $50 \mathrm{nM}$ Torin 1 to inhibit mTORC1 and mTORC2; $1 \mu \mathrm{M}$ dexamethasone was used as a reference anti-inflammatory agent (Bhattacharyya, et al. 2007). As before, LPS stimulated increased IL-1 $\alpha$, IL$1 \beta$ and IL-8 compared with control ( $\mathrm{P}<0.001$; Fig. 3 ). However, treatment with AICAR reduced LPS-stimulated IL-1 $\alpha$, IL-1 $\beta$ and IL-8 in granulosa cells from $4-8 \mathrm{~mm}$ and $>8.5 \mathrm{~mm}$ diameter follicles $(\mathrm{P}<0.05)$, and AICAR was at least as effective as dexamethasone. Rapamycin did not reduce LPS-stimulated inflammation, but Torin 1 reduced IL- $1 \alpha$ and IL-1 $\beta$ in granulosa cells from $4-8 \mathrm{~mm}$ and $>8.5 \mathrm{~mm}$ diameter follicles $(\mathrm{P}<0.05)$. 


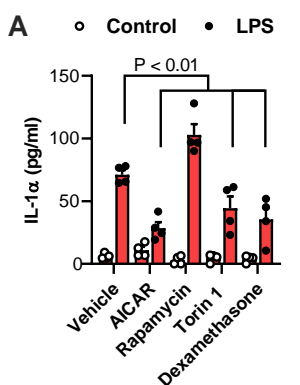

B

D

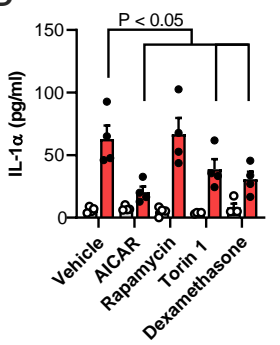

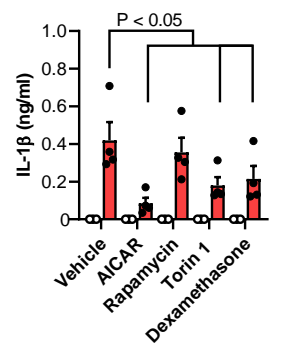

C

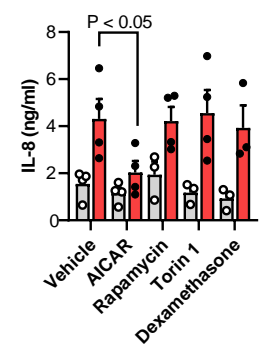

F

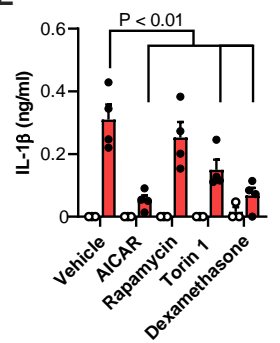

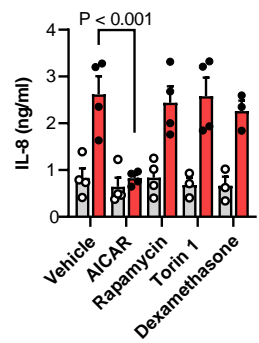

Figure 3. Intracellular metabolic sensors and granulosa cell inflammation.

Granulosa cells from 4-8 mm (A-C) or > $8.5 \mathrm{~mm}$ diameter ovarian follicles (D-F) were cultured for $2 \mathrm{~h}$ with vehicle, $1 \mathrm{mM}$ AICAR, $500 \mathrm{nM}$ rapamycin, $50 \mathrm{nM}$ Torin 1 , or $1 \mu \mathrm{M}$ dexamethasone; followed by a $24 \mathrm{~h}$ challenge with control medium (०) or medium containing $1 \mu \mathrm{g} / \mathrm{ml} \mathrm{LPS}(\bullet)$, in the presence of the treatments. Supernatant IL-1 $\alpha$ (A, D), IL-1 $\beta$ (B, E) and IL-8 (C, F) was measured by ELISA. Data from independent experiments are presented as dot plots, with bars indicating the mean (SEM). Data were analysed by two-way ANOVA, with Dunnett's post hoc test, and P-values differ between vehicle and treatments for the response to LPS.

We next considered whether reducing inflammation by inhibiting glycolysis, activating AMPK, or inhibiting mTOR simply reflected reduced protein synthesis, because these treatments can reduce phosphorylation of p70S6K, which induces protein synthesis (Kimura, et al. 2003). In granulosa cells from 4-8 mm and $>8.5 \mathrm{~mm}$ diameter follicles, rapamycin and Torin 1 alone reduced the abundance of phosphorylated p70S6K (Fig. 4). Although, there was phosphorylated p70S6K in the vehicle treatment, which might be associated with supplementation of the culture medium with serum and Insulin-Transferrin-Selenium, treatment with LPS, 2deoxy-D-glucose or AICAR did not significantly alter phosphorylation of p70S6K. Furthermore, our findings were supported by experiments where Torin 1 but not AICAR reduced the amount of protein per culture well in granulosa cells from 4-8 mm diameter follicles (Torin 1, $1.49 \pm 0.04 \mathrm{mg}$ protein vs. AICAR, $2.03 \pm 0.06 \mathrm{mg}$ or control, $2.19 \pm 0.12 \mathrm{mg} ; \mathrm{P}<0.05$, ANOVA, $\mathrm{n}=4$ ), and $>8.5 \mathrm{~mm}$ diameter follicles (Torin $1,1.32 \pm 0.12 \mathrm{mg}$ protein vs. AICAR, $1.52 \pm 0.05 \mathrm{mg}$ or control, $1.51 \pm 0.09 \mathrm{mg}$; $\mathrm{P}<0.05$, ANOVA, $\mathrm{n}=4$ ). Together, these observations suggest that activating AMPK may limit granulosa cell inflammatory responses to LPS independently of protein synthesis, and inhibiting mTOR may limit inflammatory responses by reducing protein synthesis. 

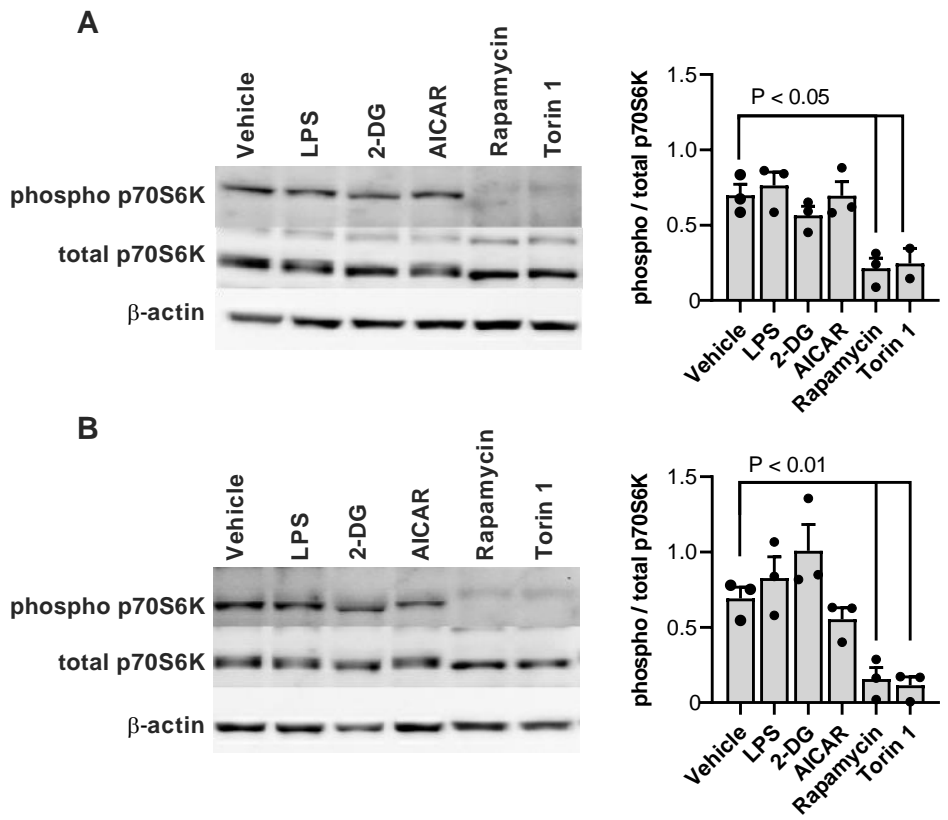

\section{Figure 4. Rapamycin and Torin 1 reduce the phosphorylation of $p 70 \mathrm{S6K}$.}

Granulosa cells from 4-8 mm (A) or $>8.5 \mathrm{~mm}$ diameter ovarian follicles (B) were treated for $24 \mathrm{~h}$ in culture medium with vehicle, $1 \mu \mathrm{g} / \mathrm{ml}$ LPS, $1 \mathrm{mM}$ 2-deoxy-D-glucose (2-DG), $1 \mathrm{mM}$ AICAR, $500 \mathrm{nM}$ rapamycin or 50 $\mathrm{nM}$ Torin 1, and the phosphorylation of p70 S6 kinase (p70S6K) analysed by Western blot. Left panels show representative Western blots of phosphorylated p70S6K, total p70S6K and $\beta$-actin (Supplemental Figure 1); right panels provide quantification of band densities for phosphorylated p70S6K relative to total p70S6K. Data from independent experiments are presented as dot plots, with bars indicating the mean (SEM). Data were analysed by one-way ANOVA, with Dunnett's post hoc test, and P-values reported for differences between the vehicle and treatments.

\section{AICAR limited granulosa cell responses to LPS}

To further investigate the effect of manipulating cellular energy metabolism, we used AICAR to activate AMPK (Corton, et al. 1995); as validated previously in bovine granulosa cells by AICAR-induced phosphorylation of AMPK (Tosca, et al. 2007). We confirmed the activity of AICAR in granulosa cells by evaluating the phosphorylation of acetyl-CoA carboxylase (ACC), which is the biomarker for activation of AMPK (González, et al. 2020, Hardie, et al. 2012). Treating granulosa cells from both 4-8 $\mathrm{mm}$ and $>8.5 \mathrm{~mm}$ diameter follicles with AICAR induced phosphorylation of ACC within $2 \mathrm{~h}$ (Fig. 5A), as well as phosphorylation of AMPK (Supplemental Figure 1). In addition, the phosphorylation of ACC was still evident after treating cells with AICAR for $24 \mathrm{~h}$ (Fig. 5B); although, LPS, 2-deoxy-D-glucose, rapamycin or Torin 1 did not significantly alter ACC phosphorylation. We next treated granulosa cells with a range of concentrations of AICAR for $2 \mathrm{~h}$ prior to and during a $24 \mathrm{~h} \mathrm{LPS}$ challenge. Treatment with AICAR reduced LPS-stimulated IL-1 $\alpha$, IL-1 $\beta$, and IL-8, without significantly altering cell viability (Fig. 5C-J). Specifically, compared with vehicle, treatment with $0.5 \mathrm{mM}$ AICAR reduced LPS-stimulated IL- $1 \alpha$ by $>60 \%$, IL- $1 \beta$ by $>75 \%$, and IL- 8 by $>20 \%$ in granulosa cells from both $4-8 \mathrm{~mm}$ and $>8.5 \mathrm{~mm}$ diameter follicles. 

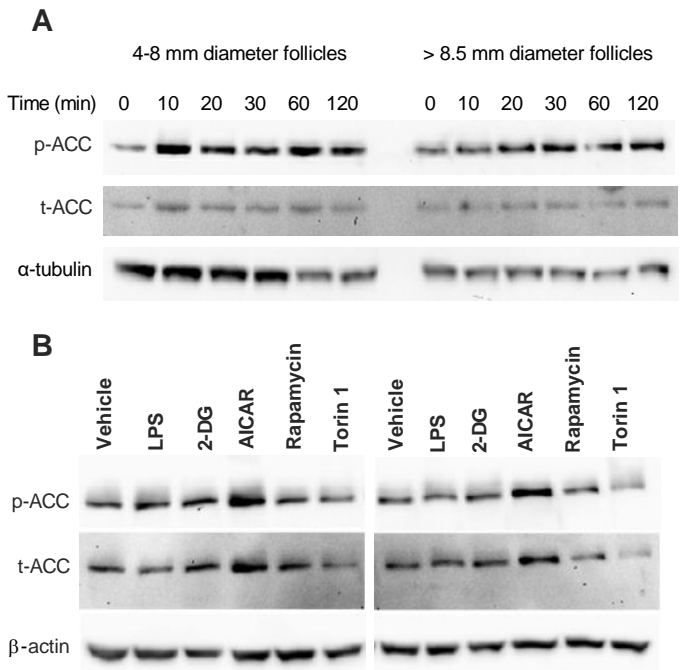
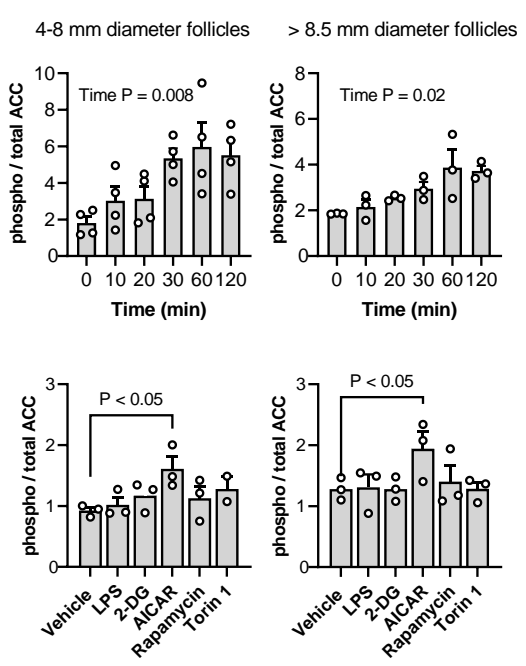

D

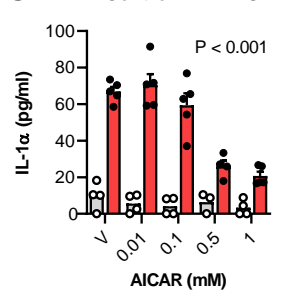

G

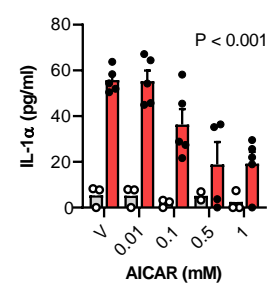

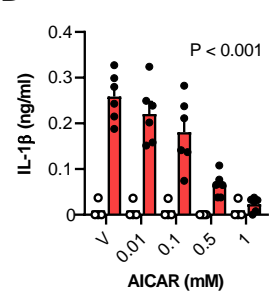

H

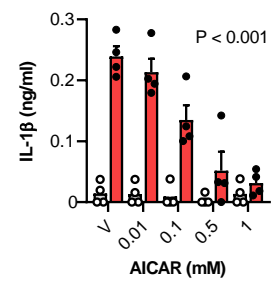

$E$

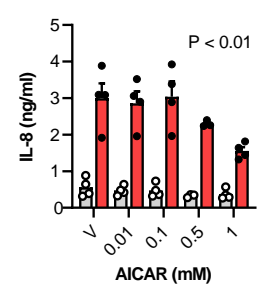

I

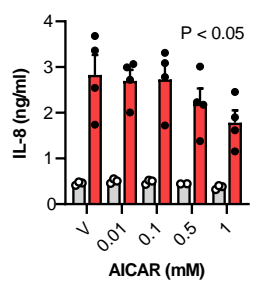

F

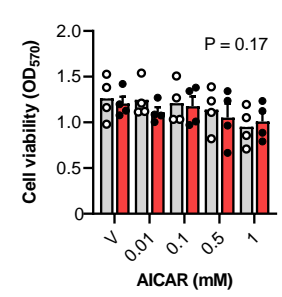

$J$

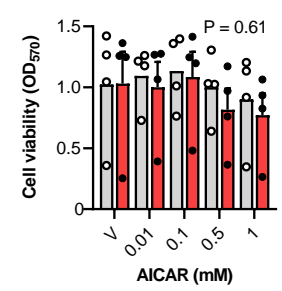

Figure 5. AICAR limits LPS-stimulated inflammation in granulosa cells.

Granulosa cells from 4-8 $\mathrm{mm}$ or $>8.5 \mathrm{~mm}$ diameter ovarian follicles were treated in culture medium with vehicle, or for the indicated times with $1 \mathrm{mM}$ AICAR (A), or for $24 \mathrm{~h}$ with $1 \mu \mathrm{g} / \mathrm{ml}$ LPS, $1 \mathrm{mM}$ 2-deoxy-D-glucose (2DG), $1 \mathrm{mM}$ AICAR, $500 \mathrm{nM}$ rapamycin or $50 \mathrm{nM}$ Torin 1 (B), and the phosphorylation of acetyl-CoA carboxylase (ACC) analysed by Western blot. Representative Western blots of phosphorylated ACC, total ACC, and $\beta$-actin or $\alpha$-tubulin are shown (left panel; Supplemental Figure 1); with quantification of band densities for phosphorylated relative to total ACC (right panel). Data from independent experiments are presented as dot plots, with bars indicating the mean (SEM). Data were analysed by ANOVA, with Dunnett's post hoc test, and P-values reported. Granulosa cells from 4-8 $\mathrm{mm}(\mathrm{C}-\mathrm{F})$ or $>8.5 \mathrm{~mm}$ diameter follicles $(\mathrm{G}-\mathrm{J})$ were treated for $2 \mathrm{~h}$ with culture medium containing vehicle (V) or the indicated final concentrations of AICAR, followed by a $24 \mathrm{~h}$ challenge with control medium or medium containing $1 \mu \mathrm{g} / \mathrm{ml}$ LPS, in the presence of the treatments. Supernatant IL-1 $\alpha(\mathrm{C}, \mathrm{G}), \mathrm{IL}-1 \beta(\mathrm{D}, \mathrm{H})$ and IL-8 (E, I) were measured by ELISA. Cell viability was assessed by MTT assay (F, J). Data from independent experiments are presented as dot plots, with bars indicating the mean (SEM). Data were analysed by two-way ANOVA, and P-values reported for the effect of AICAR on the response to LPS.

\section{AICAR truncates LPS-stimulated phosphorylation of ERK and JNK}

We then explored whether treatment with AICAR altered the MAPK response to LPS, which stimulates ERK1/2 phosphorylation in granulosa cells within 30 min (Bromfield and Sheldon 2011, Price, et al. 2013, Price and Sheldon 2013). In the present study, granulosa cells were treated for $2 \mathrm{~h}$ with vehicle or $1 \mathrm{mM}$ AICAR, and then 
challenged for up to 120 min with LPS. There was LPS-stimulated ERK1/2 phosphorylation in granulosa cells from 4-8 mm diameter follicles (Fig. 6A) and from > $8.5 \mathrm{~mm}$ diameter follicles (Fig. 6B). Although there was no significant effect of AICAR treatment, there was a shorter duration of ERK1/2 phosphorylation in cells treated with AICAR than vehicle for cells from 4-8 mm diameter (time $\times$ treatment, $\mathrm{P}<0.001$ ), and for cells from $>8.5$ mm diameter follicles (time $\times$ treatment, $\mathrm{P}<0.05$ ).

We additionally examined the phosphorylation of JNK, which was stimulated by LPS in granulosa cells from 4$8 \mathrm{~mm}$ diameter follicles (Fig. 6A) and from $>8.5 \mathrm{~mm}$ diameter follicles (Fig. 6B). Treatment with AICAR also stimulated JNK phosphorylation in granulosa cells from both follicles. However, there was a shorter duration of JNK phosphorylation in cells treated with AICAR than vehicle for cells from 4-8 mm diameter (time $\times$ treatment, $\mathrm{P}<0.05$ ), and for cells from $>8.5 \mathrm{~mm}$ diameter follicles (time $\times$ treatment, $\mathrm{P}<0.01$ ). These experiments provide evidence that AICAR reduced inflammatory responses to LPS, and truncated the LPS-stimulated phosphorylation of ERK1/2 and JNK.

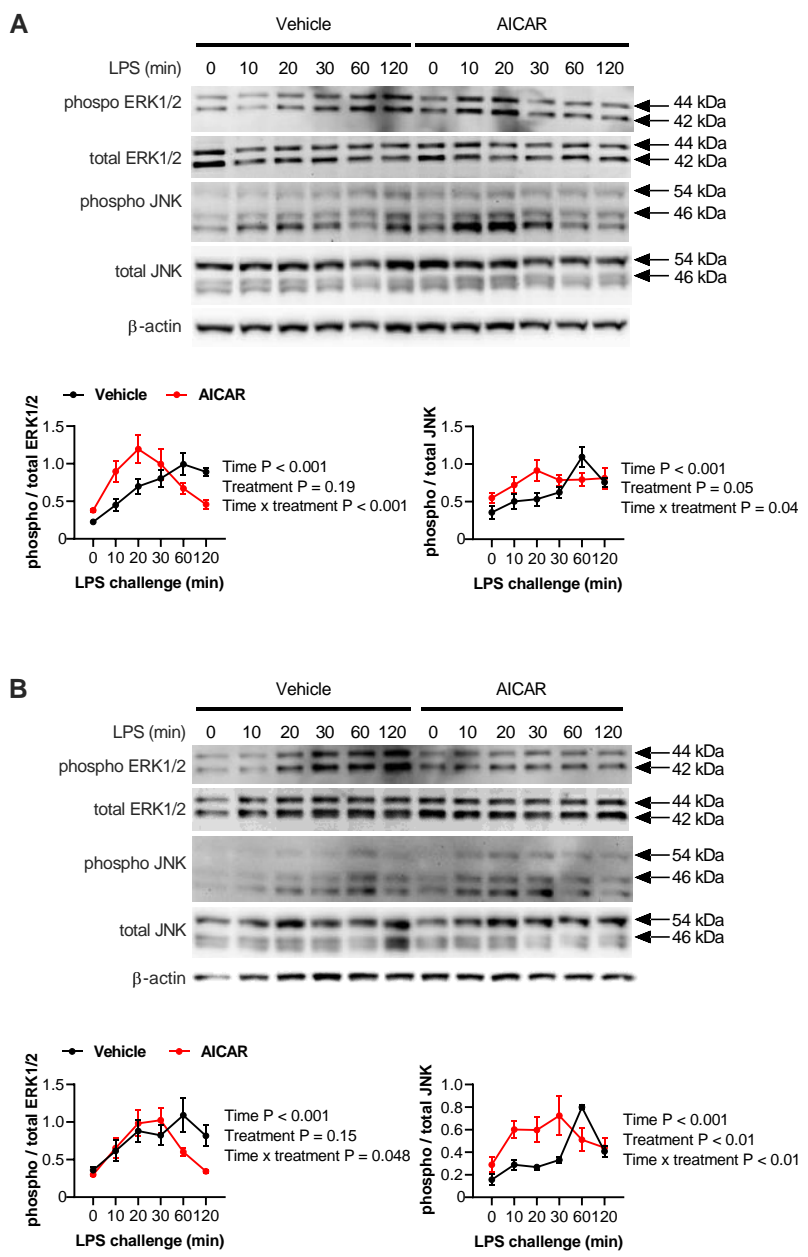

Figure 6. AICAR truncates LPS-stimulated phosphorylation of ERK and JNK.

Granulosa cells from 4-8 mm (A) or > $8.5 \mathrm{~mm}$ diameter ovarian follicles (B) were treated with vehicle or $1 \mathrm{mM}$ AICAR for $2 \mathrm{~h}$ and then challenge with $1 \mu \mathrm{g} / \mathrm{ml}$ LPS for the indicated time, and the phosphorylation of ERK1/2 and JNK analysed by Western blot. Upper panels show representative Western blots of phosphorylated and total ERK1/2, phosphorylated and total JNK, and $\beta$-actin (Supplemental Figure 1); lower panels provide quantification of band densities for phosphorylated relative to total ERK1/2 and JNK. Data are presented as mean (SEM) from 4 independent experiments; statistical significance was determined using two-way ANOVA and P-values reported. 


\section{Torin 1 limited granulosa cell IL-1 responses to LPS}

We finally considered whether inhibiting mTOR would also reduce inflammatory responses to LPS because activating AMPK in turn inhibits mTOR (Hardie, et al. 2012, Zoncu, et al. 2011). Granulosa cells were treated for $2 \mathrm{~h}$ with vehicle, or a range of concentrations of the dual mTORC1 and mTORC2 inhibitor Torin 1 (Thoreen, et al. 2009), or the mTORC1 inhibitor rapamycin (Oshiro, et al. 2004), followed by a $24 \mathrm{~h}$ control or LPS challenge, in the presence of the treatments (Fig. 7). Treatment with Torin 1 reduced LPS-stimulated IL-1 $\alpha$ and IL-1 $\beta$, but not IL-8, in cells from 4-8 mm diameter follicles (Fig. 7A-C) and from $>8.5 \mathrm{~mm}$ diameter follicles (Fig. 7E-G). Specifically, compared with vehicle, treatment with $50 \mathrm{nM}$ Torin 1 reduced LPS-stimulated IL-1 $\alpha$ by $>65 \%$ and IL- $1 \beta$ by $>50 \%$ in the supernatants of granulosa cells from $4-8 \mathrm{~mm}$ and $>8.5 \mathrm{~mm}$ diameter follicles. Although the highest concentrations of Torin 1 reduced cell viability by up to $10 \%$ (Fig. 7D, H), treatment with $50 \mathrm{nM}$ Torin 1 did not significantly alter cell viability of granulosa cells from 4-8 mm diameter follicles $(\mathrm{P}=$ $0.53)$ or from $>8.5 \mathrm{~mm}$ diameter follicles $(\mathrm{P}=0.99)$. Rapamycin did not significantly alter the inflammatory responses to LPS in cells from 4-8 mm diameter follicles or from $>8.5 \mathrm{~mm}$ diameter follicles and did not significantly alter cell viability (Fig. 7I-P).

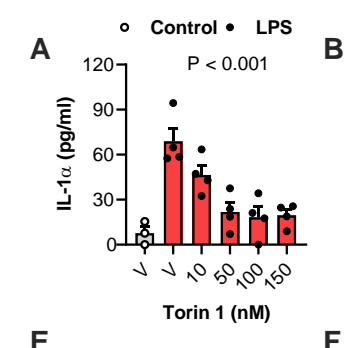

\section{E}
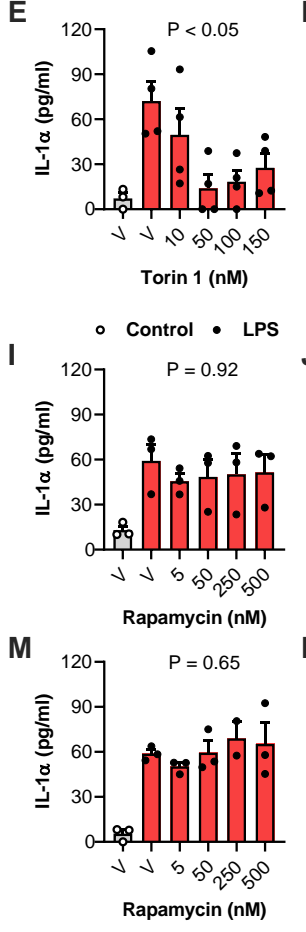

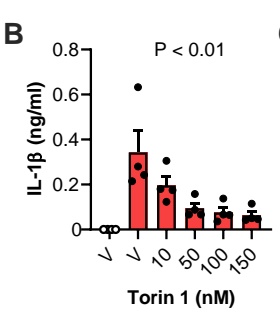

$\mathbf{F}$

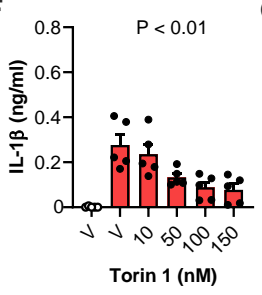

J $0.8 \quad P=0.26$
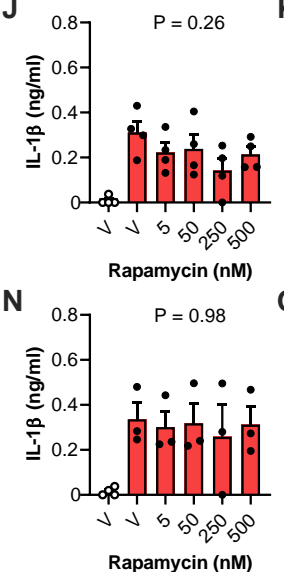

C

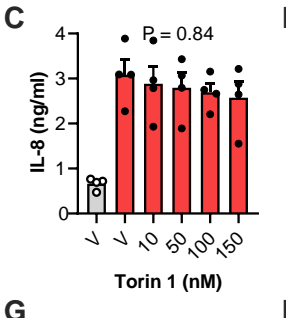

G

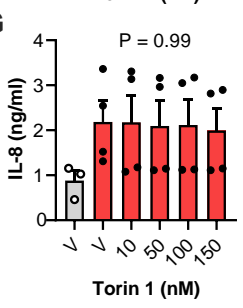

$\mathrm{K}$

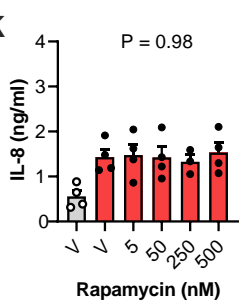

0

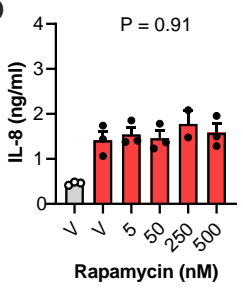

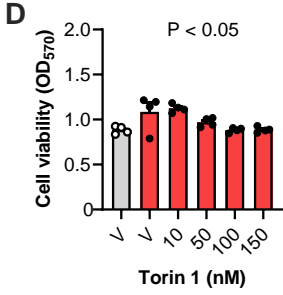

$\mathrm{H}$

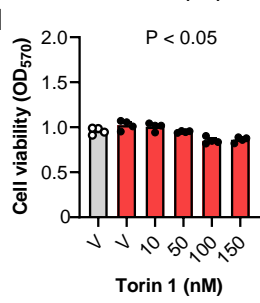

1
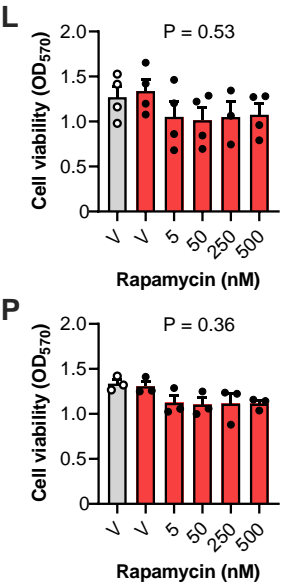

Figure 7. Torin 1 limits LPS-stimulated inflammation in granulosa cells.

Granulosa cells from 4-8 mm (A-D, I-L) or > $8.5 \mathrm{~mm}$ diameter ovarian follicles (E-H, M-P) were treated for 2 $\mathrm{h}$ with culture medium containing vehicle $(\mathrm{V})$, or the indicated final concentrations of Torin 1 or rapamycin; followed by a $24 \mathrm{~h}$ challenge with control medium or $1 \mu \mathrm{g} / \mathrm{ml} \mathrm{LPS}$, in the presence of the treatments. Supernatant IL-1 $\alpha,(\mathrm{A}, \mathrm{E}, \mathrm{I}, \mathrm{M}), \mathrm{IL}-1 \beta(\mathrm{B}, \mathrm{F}, \mathrm{J}, \mathrm{N})$ and IL-8 (C, G, K, O) was measured by ELISA; cell viability was assessed by MTT assay (D, H, L, P). Data from independent experiments are presented as dot plots, with bars indicating 
the mean (SEM). Data were analysed by one-way ANOVA, and P-values are reported for the effect of treatment on the LPS response.

As Torin 1 reduced inflammation, we next explored whether Torin 1 altered LPS-stimulated phosphorylation of MAPK. Granulosa cells were treated for $2 \mathrm{~h}$ with vehicle or $50 \mathrm{nM}$ Torin 1, and then challenged for up to 120 min with LPS. As before, LPS stimulated phosphorylation of ERK1/2 and JNK in granulosa cells from 4-8 mm diameter follicles (Fig. 8A), and from $>8.5 \mathrm{~mm}$ diameter follicles (Fig. 8B). However, Torin 1 did not significantly alter the duration of ERK1/2 or JNK phosphorylation. Together, these data suggest that whilst Torin 1 reduced IL-1 responses to LPS, Torin 1 did not alter the duration of MAPK phosphorylation.
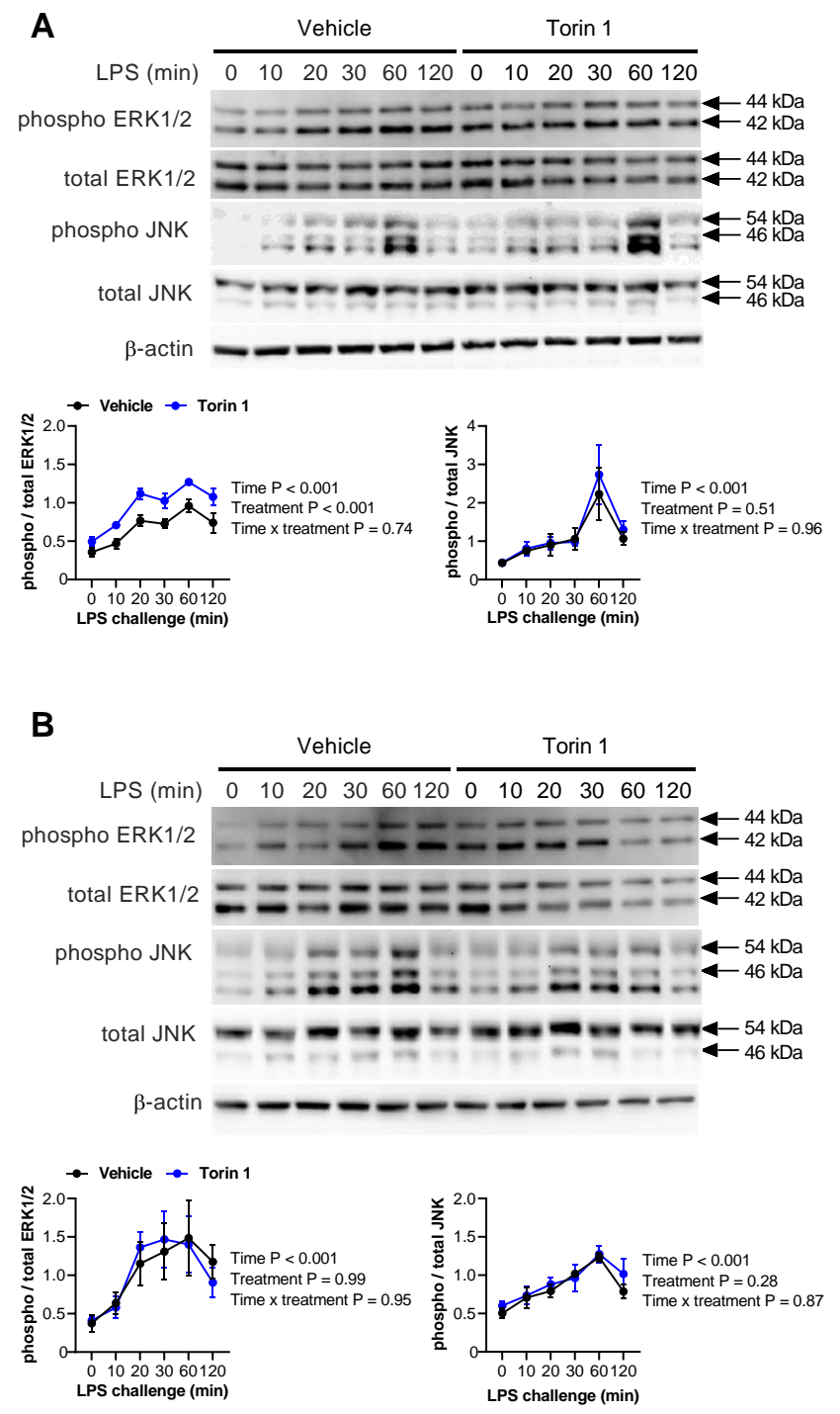

Figure 8. Torin 1 did not alter LPS-stimulated phosphorylation of MAPK.

Granulosa cells from 4-8 mm (A) or > $8.5 \mathrm{~mm}$ diameter ovarian follicles (B) were treated with vehicle or $50 \mathrm{nM}$ Torin 1 for $2 \mathrm{~h}$ and then challenge with $1 \mu \mathrm{g} / \mathrm{ml}$ LPS for the indicated times, and the phosphorylation of ERK1/2 and JNK analysed by Western blot. Upper panels show representative Western blots of phosphorylated and total ERK1/2, phosphorylated and total JNK, and $\beta$-actin (Supplemental Figure 1); lower panels provide quantification of band densities for phosphorylated relative to total ERK1/2 and JNK. Data are presented as mean (SEM) from 4 independent experiments; statistical significance was determined using two-way ANOVA and P-values reported. 


\section{Discussion}

Innate immunity and energy stress are both important in granulosa cells because ovarian follicles are often exposed to LPS after parturition, which is when cows are unable to consume enough food to meet their energy demands (Beam and Butler 1997, Cheong, et al. 2017, Herath, et al. 2007, Leroy, et al. 2004, Piersanti, et al. 2019). In the present study, we found that LPS stimulated phosphorylation of ERK1/2 and JNK, and stimulated the release of IL-1 $\alpha$, IL-1 $\beta$ and IL-8. However, our main finding was that energy stress limited inflammation in bovine granulosa cells. Inflammatory responses to LPS were limited by the glycolysis inhibitor 2-deoxy-D-glucose, the AMPK activator AICAR, or the mTOR inhibitor Torin 1. Furthermore, AICAR truncated LPS-stimulated phosphorylation of ERK1/2 and JNK. The effects of manipulating energy metabolism on the responses to LPS were similar for granulosa cells isolated from both $4-8 \mathrm{~mm}$ and $>8.5 \mathrm{~mm}$ diameter ovarian follicles. Collectively, the data provide evidence for an immunometabolism crosstalk in granulosa cells and imply that energy stress limits ovarian follicle defences.

We first generated energy stress by inhibiting hexokinase with 2-deoxy-D-glucose to prevent glycolysis (Lee, et al. 2020, Tannahill, et al. 2013, Zhao, et al. 2017). Inhibiting glycolysis reduced LPS-stimulated IL-1 $\alpha$, IL-1 $\beta$, and IL-8 in granulosa cells from $4-8 \mathrm{~mm}$ and $>8.5 \mathrm{~mm}$ diameter ovarian follicles. This reduced inflammation is similar to findings with murine macrophages, where inhibiting hexokinase reduces LPS-stimulated IL- $1 \beta$ (Tannahill, et al. 2013). Inhibiting hexokinase or depleting glucose and glutamine, also limits LPS-stimulated IL-1 $\beta$, IL-6 and IL-8 in bovine endometrial tissue (Noleto, et al. 2017, Turner, et al. 2016). When follicular fluid was collected from cows 63 days post partum, intrafollicular IL-8 and LPS concentrations were correlated as might be expected, but more interestingly intrafollicular IL-8 and glucose concentrations were also correlated $\left(\mathrm{r}^{2}=0.77\right)$ (Piersanti, et al. 2019). Transcriptomic analysis has also suggested that energy stress impairs inflammatory responses to LPS in granulosa cells collected from postpartum cows (Girard, et al. 2015).

Cellular energy metabolism is regulated by AMPK and mTOR in most eukaryotic cells (Hardie, et al. 2012, Murray, et al. 2015, O'Neill, et al. 2016, Zoncu, et al. 2011). The energy sensor AMPK is activated by energy stress or by small molecules such as AICAR (Hardie, et al. 2012, Tosca, et al. 2007, Tosca, et al. 2010). Activating AMPK regulates energy metabolism by stimulating glucose uptake, glycolysis and the Krebs cycle to produce ATP (Hardie, et al. 2012). Activating AMPK also inhibits mTOR and pathways that consume ATP, including inhibition of lipid metabolism via phosphorylation of acetyl-CoA carboxylase. In the present study, AICAR increased phosphorylation of acetyl-CoA carboxylase, confirming previous observations that AICAR activates AMPK in bovine granulosa cells (Tosca, et al. 2007). More importantly, treatment with AICAR reduced LPSstimulated IL-1 $\alpha$, IL- $1 \beta$ and IL- 8 in granulosa cells, with $0.5 \mathrm{mM}$ AICAR reducing LPS-stimulated IL- $1 \alpha$ by > $60 \%$, IL- $1 \beta$ by $>75 \%$, and IL- 8 by $>20 \%$. Our finding agrees with previous observations that AICAR reduces LPS-stimulated TNF- $\alpha$ and IL- 6 in murine neutrophils, and IL-1 $\beta$, IL-6 and IL- 8 in bovine endometrial tissue (Turner, et al. 2016, Zhao, et al. 2008). Surprisingly, the responses to LPS and the effects of energy stress in the present study were similar for granulosa cells from both 4-8 $\mathrm{mm}$ and $>8.5 \mathrm{~mm}$ diameter ovarian follicles, despite developmental differences between these follicle sizes (Fortune 1994, Ginther, et al. 1996). This consistent immunometabolism effect may reflect the evolutionary importance of integrating defence with metabolism.

One concern was that the reductions in inflammation were simply caused by reduced protein synthesis. However, AICAR did not inhibit phosphorylation of p70S6K or reduce total cellular protein. Instead, AICAR reduced the duration of LPS-stimulated phosphorylation of ERK1/2 and JNK. This observation is similar to a reduction in FSH-induced phosphorylation of ERK1/2, when bovine granulosa cells were treated with metformin, which also activates AMPK (Tosca, et al. 2007, Tosca, et al. 2010).

Activating AMPK can in turn regulate energy metabolism by inhibiting mTOR (Hardie, et al. 2012, Zoncu, et al. 2011). We found that granulosa cell IL- $1 \alpha$ and IL-1 $\beta$ responses to LPS were reduced by Torin 1 , but not by rapamycin, and MAPK phosphorylation was unaffected. The different IL-1 responses between Torin 1 and rapamycin may be because Torin 1 inhibits both mTORC1 and mTORC2, whereas rapamycin inhibits only mTORC1 (Oshiro, et al. 2004, Thoreen, et al. 2009). Another possibility is that Torin 1 reduced LPS-stimulated inflammation by more effectively reducing protein synthesis, because Torin 1 reduced the phosphorylation of p70S6K and the amount of cellular protein. 
The observation was that depleting glucose did not limit inflammatory responses to LPS was unexpected because responses to LPS are energetically expensive (Kvidera, et al. 2017). The lack of effect of glucose depletion on granulosa cell inflammation might be because the fetal bovine serum in the culture medium supplied $0.79 \mathrm{mM}$ glucose, or because of the metabolic flexibility of cells to use alternative energy sources, including glutamine and lipids (Reitzer, et al. 1979). Another explanation might be because directly inhibiting glycolysis with 2-deoxy-Dglucose has widespread impacts on cell metabolism (O'Neill, et al. 2016, Tannahill, et al. 2013). Future studies could investigate whether components of the glycolysis pathway or Krebs cycle impinge directly on granulosa cell inflammatory responses because acetyl-CoA, succinate and fumarate all regulate inflammation in immune cells (Ryan, et al. 2019). Another intriguing observation worthy of further investigation is that whilst AICAR, Torin 1 and dexamethasone reduced LPS-stimulated IL-1, only AICAR reduced IL-8, which may reflect differences in the regulation of IL-1 and IL-8 production or secretion (Hoffmann, et al. 2002).

In conclusion, granulosa cell inflammatory responses to LPS were limited by manipulating cellular energy metabolism using a glycolysis inhibitor, an AMPK activator, or an mTOR inhibitor. Specifically, in cells isolated from ovarian follicles 4-8 mm and > $8.5 \mathrm{~mm}$ diameter, 2-deoxy-D-glucose and AICAR limited LPS-stimulated IL- $1 \alpha$, IL-1 $\beta$ and IL-8, and Torin 1 limited IL- $1 \alpha$ and IL-1 $\beta$. These observations are an example of immunometabolism, linking cellular energy metabolism with innate immunity in granulosa cells. Our findings also imply that energy stress compromises ovarian follicle immune defences, which may reduce the capability of cows to cope with the effect of infections on fertility.

\section{Disclosure}

The authors declare that there is no conflict of interest that could be perceived as prejudicing the impartiality of the research reported.

\section{Funding}

This work was supported by the Eunice Kennedy Shriver National Institute of Child Health \& Human Development of the National Institutes of Health (R01HD084316), and a Swansea University Research Scholarship. The content is solely the responsibility of the authors and does not necessarily represent the official views of the National Institutes of Health.

\section{Author contributions}

Conceptualization IMS, JJB, ADH; methodology ADH, IMS; investigation ADH; formal analysis ADH, IMS; writing - original draft preparation ADH, IMS; writing - review and editing IMS, ADH, TJRO, MJDC, JJB, JEPS; visualization ADH, IMS; supervision IMS, MJDC, JJB; project administration IMS, JJB; funding acquisition JJB, IMS, JEPS.

\section{Acknowledgements}

We thank Dr J Cronin and Dr S Owens for technical advice.

\section{References}

Aft RL, Zhang FW \& Gius D 2002 Evaluation of 2-deoxy-D-glucose as a chemotherapeutic agent: mechanism of cell death. British Journal of Cancer 87 805-812.

Beam SW \& Butler WR 1997 Energy balance and ovarian follicle development prior to the first ovulation postpartum in dairy cows receiving three levels of dietary fat. Biology of Reproduction 56 133-142.

Bhattacharyya S, Brown DE, Brewer JA, Vogt SK \& Muglia LJ 2007 Macrophage glucocorticoid receptors regulate Toll-like receptor 4-mediated inflammatory responses by selective inhibition of p38 MAP kinase. Blood 109 4313-4319.

Bidne KL, Dickson MJ, Ross JW, Baumgard LH \& Keating AF 2018 Disruption of female reproductive function by endotoxins. Reproduction 155 R169-181.

Bromfield JJ, Santos JE, Block J, Williams RS \& Sheldon IM 2015 PHYSIOLOGY AND ENDOCRINOLOGY SYMPOSIUM: Uterine infection: linking infection and innate immunity with infertility in the high-producing dairy cow. Journal of Animal Science 93 2021-2033.

Bromfield JJ \& Sheldon IM 2011 Lipopolysaccharide initiates inflammation in bovine granulosa cells via the TLR4 pathway and perturbs oocyte meiotic progression in vitro. Endocrinology 152 5029-5040. 
Cheong SH, OG SF, Absalon-Medina VA, Schneider A, Butler WR \& Gilbert RO 2017 Uterine and systemic inflammation influences ovarian follicular function in postpartum dairy cows. PLoS One 12 e0177356.

Corton JM, Gillespie JG, Hawley SA \& Hardie DG 1995 5-aminoimidazole-4-carboxamide ribonucleoside. A specific method for activating AMP-activated protein kinase in intact cells? European Journal of Biochemistry 229 558-565.

Cronin JG, Hodges R, Pedersen S \& Sheldon IM 2015 Enzyme linked immunosorbent assay for quantification of bovine interleukin-8 to study infection and immunity in the female genital tract. American Journal of Reproductive Immunology 73 372-382.

Dosogne H, Meyer E, Sturk A, van Loon J, Massart-Leën AM \& Burvenich C 2002 Effect of enrofloxacin treatment on plasma endotoxin during bovine Escherichia coli mastitis. Inflammation Research 51 201205.

Dror E, Dalmas E, Meier DT, Wueest S, Thévenet J, Thienel C, Timper K, Nordmann TM, Traub S, Schulze F, et al. 2017 Postprandial macrophage-derived IL-1 $\beta$ stimulates insulin, and both synergistically promote glucose disposal and inflammation. Nature Immunology 18 283-292.

Fortune JE 1994 Ovarian follicular growth and development in mammals. Biology of Reproduction 50 225-232.

Gérard N, Caillaud M, Martoriati A, Goudet G \& Lalmanach AC 2004 The interleukin-1 system and female reproduction. Journal of Endocrinology 180 203-212.

Gindri P, de Ávila Castro N, Mion B, Garziera Gasperin B, Catarelli Pegoraro LM, Alveiro Alvarado Rincón J, Diniz Vieira A, Pradieé J, Machado Pfeifer LF, Nunes Corrêa M, et al. 2019 Intrafollicular lipopolysaccharide injection delays ovulation in cows. Animal Reproduction Science 211106226.

Ginther OJ, Wiltbank MC, Fricke PM, Gibbons JR \& Kot K 1996 Selection of the dominant follicle in cattle. Biology of Reproduction 55 1187-1194.

Girard A, Dufort I \& Sirard MA 2015 The effect of energy balance on the transcriptome of bovine granulosa cells at 60 days postpartum. Theriogenology 84 1350-1361.

Giubellino A, Bullova P, Nölting S, Turkova H, Powers JF, Liu Q, Guichard S, Tischler AS, Grossman AB \& Pacak K 2013 Combined inhibition of mTORC1 and mTORC2 signaling pathways is a promising therapeutic option in inhibiting pheochromocytoma tumor growth: in vitro and in vivo studies in female athymic nude mice. Endocrinology 154 646-655.

González A, Hall MN, Lin SC \& Hardie DG 2020 AMPK and TOR: The Yin and Yang of Cellular Nutrient Sensing and Growth Control. Cell Metabolism 31 472-492.

Habel J \& Sundrum A 2020 Mismatch of glucose allocation between different life functions in the transition period of dairy cows. Animals (Basel) $\mathbf{1 0} 1028$.

Hammon DS, Evjen IM, Dhiman TR, Goff JP \& Walters JL 2006 Neutrophil function and energy status in Holstein cows with uterine health disorders. Veterinary Immunology and Immunopathology 113 21-29.

Hardie DG, Ross FA \& Hawley SA 2012 AMPK: a nutrient and energy sensor that maintains energy homeostasis. Nature Reviews: Molecular Cell Biology 13 251-262.

Healy LL, Cronin JG \& Sheldon IM 2014 Endometrial cells sense and react to tissue damage during infection of the bovine endometrium via interleukin 1. Scientific Reports 47060.

Herath S, Williams EJ, Lilly ST, Gilbert RO, Dobson H, Bryant CE \& Sheldon IM 2007 Ovarian follicular cells have innate immune capabilities that modulate their endocrine function. Reproduction 134 683693.

Hirschfeld M, Ma Y, Weis JH, Vogel SN \& Weis JJ 2000 Cutting edge: repurification of lipopolysaccharide eliminates signaling through both human and murine Toll-like receptor 2. Journal of Immunology 165 618-622.

Hoffmann E, Dittrich-Breiholz O, Holtmann H \& Kracht M 2002 Multiple control of interleukin-8 gene expression. Journal of Leukocyte Biology 72 847-855.

Irving-Rodgers HF, van Wezel IL, Mussard ML, Kinder JE \& Rodgers RJ 2001 Atresia revisited: two basic patterns of atresia of bovine antral follicles. Reproduction 122 761-775.

Khafipour E, Krause DO \& Plaizier JC 2009 A grain-based subacute ruminal acidosis challenge causes translocation of lipopolysaccharide and triggers inflammation. Journal of Dairy Science 92 1060-1070.

Kim JE, Kim YW, Lee IK, Kim JY, Kang YJ \& Park SY 2008 AMP-activated protein kinase activation by 5aminoimidazole-4-carboxamide-1-beta-D-ribofuranoside (AICAR) inhibits palmitate-induced endothelial cell apoptosis through reactive oxygen species suppression. Journal of Pharmacolgical Methods 106 394-403. 
Kimura N, Tokunaga C, Dalal S, Richardson C, Yoshino K, Hara K, Kemp BE, Witters LA, Mimura O \& Yonezawa K 2003 A possible linkage between AMP-activated protein kinase (AMPK) and mammalian target of rapamycin (mTOR) signalling pathway. Genes to Cells 8 65-79.

Kvidera SK, Horst EA, Abuajamieh M, Mayorga EJ, Fernandez MV \& Baumgard LH 2017 Glucose requirements of an activated immune system in lactating Holstein cows. Journal of Dairy Science $\mathbf{1 0 0}$ 2360-2374.

Lachmandas E, Boutens L, Ratter JM, Hijmans A, Hooiveld GJ, Joosten LA, Rodenburg RJ, Fransen JA, Houtkooper RH, van Crevel R, et al. 2016 Microbial stimulation of different Toll-like receptor signalling pathways induces diverse metabolic programmes in human monocytes. Nature Microbiology 216246.

LeBlanc SJ 2012 Interactions of metabolism, inflammation, and reproductive tract health in the postpartum period in dairy cattle. Reproduction in Domestic Animals 47 Suppl 5 18-30.

LeBlanc SJ, Duffield TF, Leslie KE, Bateman KG, Keefe GP, Walton JS \& Johnson WH 2002 Defining and diagnosing postpartum clinical endometritis and its impact on reproductive performance in dairy cows. Journal of Dairy Science $\mathbf{8 5}$ 2223-2236.

Lee H, Zandkarimi F, Zhang Y, Meena JK, Kim J, Zhuang L, Tyagi S, Ma L, Westbrook TF, Steinberg GR, et al. 2020 Energy-stress-mediated AMPK activation inhibits ferroptosis. Nature Cell Biology 22 225-234.

Leroy J, Vanholder T, Van Knegsel A, Garcia-Ispierto I \& Bols P 2008 Nutrient prioritization in dairy cows early postpartum: mismatch between metabolism and fertility? Reproduction in Domestic Animals $\mathbf{4 3}$ 96-103.

Leroy JL, Vanholder T, Delanghe JR, Opsomer G, Van Soom A, Bols PE, Dewulf J \& de Kruif A 2004 Metabolic changes in follicular fluid of the dominant follicle in high-yielding dairy cows early post partum. Theriogenology 62 1131-1143.

Moresco EM, LaVine D \& Beutler B 2011 Toll-like receptors. Current Biology 21 R488-493.

Murray PJ, Rathmell J \& Pearce E 2015 SnapShot: Immunometabolism. Cell Metabolism 22 190-190.

Noleto PG, Saut JPE \& Sheldon IM 2017 Short communication: Glutamine modulates inflammatory responses to lipopolysaccharide in ex vivo bovine endometrium. Journal of Dairy Science 100 2207-2212.

O'Neill LAJ, Kishton RJ \& Rathmell J 2016 A guide to immunometabolism for immunologists. Nature Reviews: Immunology 16 553-565.

Oshiro N, Yoshino K, Hidayat S, Tokunaga C, Hara K, Eguchi S, Avruch J \& Yonezawa K 2004 Dissociation of raptor from mTOR is a mechanism of rapamycin-induced inhibition of mTOR function. Genes to Cells 9 359-366.

Piersanti RL, Zimpel R, Molinari PCC, Dickson MJ, Ma Z, Jeong KC, Santos JEP, Sheldon IM \& Bromfield JJ 2019 A model of clinical endometritis in Holstein heifers using pathogenic Escherichia coli and Trueperella pyogenes. Journal of Dairy Science 102 2686-2697.

Price JC, Bromfield JJ \& Sheldon IM 2013 Pathogen-associated molecular patterns initiate inflammation and perturb the endocrine function of bovine granulosa cells from ovarian dominant follicles via TLR2 and TLR4 pathways. Endocrinology 154 3377-3386.

Price JC \& Sheldon IM 2013 Granulosa cells from emerged antral follicles of the bovine ovary initiate inflammation in response to bacterial pathogen-associated molecular patterns via Toll-like receptor pathways. Biology of Reproduction 89119.

Reitzer LJ, Wice BM \& Kennell D 1979 Evidence that glutamine, not sugar, is the major energy source for cultured HeLa cells. Journal of Biological Chemistry 254 2669-2676.

Ryan DG, Murphy MP, Frezza C, Prag HA, Chouchani ET, O’Neill LA \& Mills EL 2019 Coupling Krebs cycle metabolites to signalling in immunity and cancer. Nature Metabolism 1 16-33.

Schindelin J, Arganda-Carreras I, Frise E, Kaynig V, Longair M, Pietzsch T, Preibisch S, Rueden C, Saalfeld S, Schmid B, et al. 2012 Fiji: an open-source platform for biological-image analysis. Nature Methods 9 676-682.

Sheldon IM, Cronin JG \& Bromfield JJ 2019 Tolerance and innate immunity shape the development of postpartum uterine disease and the impact of endometritis in dairy cattle. Annual Review of Animal Biosciences 7 361-384.

Sheldon IM, Noakes DE, Rycroft AN, Pfeiffer DU \& Dobson H 2002 Influence of uterine bacterial contamination after parturition on ovarian dominant follicle selection and follicle growth and function in cattle. Reproduction 123 837-845. 
Shen M, Jiang Y, Guan Z, Cao Y, Li L, Liu H \& Sun S-c 2017 Protective mechanism of FSH against oxidative damage in mouse ovarian granulosa cells by repressing autophagy. Autophagy 13 1364-1385.

Spanel-Borowski K, Rahner P \& Ricken AM 1997 Immunolocalization of CD18-positive cells in the bovine ovary. Journal of Reproduction and Fertility 111 197-205.

Spicer LJ \& Alpizar E 1994 Effects of cytokines on FSH-induced estradiol production by bovine granulosa cells in vitro: dependence on size of follicle. Domestic Animal Endocrinology 11 25-34.

Tannahill GM, Curtis AM, Adamik J, Palsson-McDermott EM, McGettrick AF, Goel G, Frezza C, Bernard NJ, Kelly B, Foley NH, et al. 2013 Succinate is an inflammatory signal that induces IL-1beta through HIF-1alpha. Nature 496 238-242.

Thoreen CC, Kang SA, Chang JW, Liu Q, Zhang J, Gao Y, Reichling LJ, Sim T, Sabatini DM \& Gray NS 2009 An ATP-competitive mammalian target of rapamycin inhibitor reveals rapamycin-resistant functions of mTORC1. Journal of Biological Chemistry 284 8023-8032.

Tosca L, Chabrolle C, Uzbekova S \& Dupont J 2007 Effects of metformin on bovine granulosa cells steroidogenesis: possible involvement of adenosine 5' monophosphate-activated protein kinase (AMPK). Biology of Reproduction 76 368-378.

Tosca L, Crochet S, Ferre P, Foufelle F, Tesseraud S \& Dupont J 2006 AMP-activated protein kinase activation modulates progesterone secretion in granulosa cells from hen preovulatory follicles. Journal of Endocrinology 190 85-97.

Tosca L, Froment P, Solnais P, Ferre P, Foufelle F \& Dupont J 2005 Adenosine 5'-monophosphate-activated protein kinase regulates progesterone secretion in rat granulosa cells. Endocrinology 146 4500-4513.

Tosca L, Rame C, Chabrolle C, Tesseraud S \& Dupont J 2010 Metformin decreases IGF1-induced cell proliferation and protein synthesis through AMP-activated protein kinase in cultured bovine granulosa cells. Reproduction 139 409-418.

Turner ML, Cronin JG, Noleto PG \& Sheldon IM 2016 Glucose availability and AMP-activated protein kinase link energy metabolism and innate immunity in the bovine endometrium. PLoS One 11 e 0151416.

Uri-Belapolsky S, Shaish A, Eliyahu E, Grossman H, Levi M, Chuderland D, Ninio-Many L, Hasky N, Shashar D, Almog T, et al. 2014 Interleukin-1 deficiency prolongs ovarian lifespan in mice. Proceedings of the National Academy of Sciences of the United States of America 111 12492-12497.

Zhang Z, Amorosa LF, Petrova A, Coyle S, Macor M, Nair M, Lee LY \& Haimovich B 2019 TLR4 counteracts BVRA signaling in human leukocytes via differential regulation of AMPK, mTORC1 and mTORC2. Scientific Reports 97020.

Zhao X, Zmijewski JW, Lorne E, Liu G, Park Y-J, Tsuruta Y \& Abraham E 2008 Activation of AMPK attenuates neutrophil proinflammatory activity and decreases the severity of acute lung injury. American Journal of Physiology-Lung Cellular and Molecular Physiology 295 L497-L504.

Zhao Y, Hu X, Liu Y, Dong S, Wen Z, He W, Zhang S, Huang Q \& Shi M 2017 ROS signaling under metabolic stress: cross-talk between AMPK and AKT pathway. Molecular Cancer 1679.

Zoncu R, Efeyan A \& Sabatini DM 2011 mTOR: from growth signal integration to cancer, diabetes and ageing. Nature Reviews: Molecular Cell Biology 12 21-35. 